\title{
Investigation in relationship between Free Cash Flow (FCF) theory and overinvestment and role of mechanism of corporate governance in iranian gapital market
}

Fatemeh Montazeri

Department of Accounting, Yadegar-E-Imam khomeini (RAH), Shahre Rey Branch, IslamicAzad University, Tehran, Iran

fatemeh.montazeri.1367@gmail.com

Ramin Varan

Department of Accounting, Firoozkooh Branch, Islamic Azad University, Firoozkooh, Iran Raminvaran@yahoo.com

Editor Científico: José Edson Lara

Organização Comitê Científico

Double Blind Review pelo SEER/OJS

Recebido em 05.07.2019

Aprovado em 08.11.2019

\section{(c) (1) (9)}

Este trabalho foi licenciado com uma Licença Creative Commons - Atribuição - Não Comercial 3.0 Brasil 

market

\begin{abstract}
The present research analyzed the relationship among Free Cash Flow (FCF) Theory and overinvestment with the role of corporate governance. Three variables have been utilized to examine corporate governance i.e. size of board and independence of directors and institutional investors. The statistical population of this study comprises of 119 enterprises listed in Tehran Security and Exchange Organization TSEO within time interval (2010-16). E-view software was used for analysis of research hypotheses and the mixed data technique was adapted. The results of research analyses indicated that the variables of free cash flows and institutional investors caused increase and decrease in overinvestment respectively. Similarly, the findings derived from this study suggest that the variables of size and independence of directors were not significantly related to overinvestment in the company. Finally, further research investigations showed that there had no significant effect by variables of corporate governance, size of board of directors and independence of directors on relationship among free cash flows and overinvestment and only variable of corporate institutional investor could affect this relationship.
\end{abstract}

Keywords: Free Cash Flow (FCF) Theory, Overinvestment, Corporate Governance

\title{
Investigação da relação entre a teoria do Fluxo de Caixa Livre (FCF) e o superinvestimento e o papel do mecanismo de governança corporativa no mercado de capital iraniano
}

\section{Resumo}

A presente pesquisa analisou a relação entre a teoria do fluxo de caixa livre (FCF) e o superinvestimento com o papel da governança corporativa. Três variáveis foram utilizadas para examinar a governança corporativa, ou seja, tamanho do conselho e independência dos diretores e investidores institucionais. A população estatística deste estudo é composta por 119 empresas listadas no TSEO da Organização de Segurança e Intercâmbio de Teerã no intervalo de tempo (2010-16). O software E-view foi utilizado para análise de hipóteses de pesquisa e a técnica de dados mistos foi adaptada. Os resultados das análises da pesquisa indicaram que as variáveis de fluxos de caixa livres e investidores institucionais causaram aumento e diminuição do excesso de investimento, respectivamente. Da mesma forma, os resultados derivados deste estudo sugerem que as variáveis de tamanho e independência dos diretores não estavam significativamente relacionadas ao superinvestimento na empresa. Finalmente, investigações posteriores mostraram que não houve efeito significativo de variáveis de governança corporativa, tamanho do conselho de administração e independência dos conselheiros na relação entre fluxos de caixa livres e superinvestimento, e apenas a variável do investidor institucional corporativo poderia afetar esse relacionamento.

Palavras-chave: Teoria do Fluxo de Caixa Livre (FCF), Superinvestimento, Governança Corporativa 


\section{Investigación de la relación entre la teoría del Flujo de Caja Libre (FCF) y la sobreinversión y el papel del mecanismo de gobierno corporativo en el mercado de capital iraní}

\section{Resumen}

La presente investigación analizó la relación entre la teoría del flujo de caja libre (FCF) y la sobreinversión con el papel del gobierno corporativo. Se han utilizado tres variables para examinar el gobierno corporativo, es decir, el tamaño de la junta y la independencia de los directores e inversores institucionales. La población estadística de este estudio se compone de 119 empresas incluidas en TSEO de la Organización de Seguridad e Intercambio de Teherán dentro del intervalo de tiempo (2010-16). Se utilizó el software E-view para el análisis de hipótesis de investigación y se adaptó la técnica de datos mixtos. Los resultados de los análisis de investigación indicaron que las variables de los flujos de caja libres y los inversores institucionales causaron un aumento y una disminución de la sobreinversión, respectivamente. Del mismo modo, los resultados derivados de este estudio sugieren que las variables de tamaño e independencia de los directores no estaban significativamente relacionadas con la sobreinversión en la empresa. Finalmente, investigaciones adicionales mostraron que las variables de gobierno corporativo, el tamaño de la junta directiva y la independencia de los directores no tuvieron un efecto significativo en la relación entre los flujos de efectivo libres y la sobreinversión, y solo una variable del inversor institucional corporativo podría afectar esta relación.

Palabras clave: Teoría del flujo de caja libre (FCF), sobreinversión, gobierno corporativo

\section{Introduction}

The director enjoy potential for selection of various administrative strategies in execution of commercial plans each of these techniques will be led to creation of different cash flows and finally managerial return requires for taking optimal strategies to lead to the highest expected value for the given enterprise. Alternately, investment can play vital and key role in economic growth and development (Moradi \& Bagheri, 2014). In fact, it should be invested in any trading unit with respect to limitation of sources and related efficiency, but the main point lies in selection of projects and making decision on investment opportunities by directors of commercial units for which it is done according to their personal interests. In other words, information asymmetry and conflict of interests prevent from an optimal investment (Yang and Jiang, 2008). The free cash flow is one of the effective factors in creating overinvestment in a trading unit. In trading units with high free cash flows, directors invest in those projects that create non-monetary return and cause developing investment in the given trading unit and 
consequently lead to overinvestment (Jensen, 1986). In addition to suitable growth opportunities to investment, there are some other factors such as type of relations between directors and beneficiaries and personality characteristics of directors and fluctuations in markets that may influence in corporate investment fundamentally. Yang and Jiang argue that inadequate investment originates from agency theory and theory of economic information and some issues e.g. agency costs and information asymmetry (Yang \& Jiang, 2008). In this regard, it seems necessary to achieve some criteria thereby to affect indirectly investment decisions made by directors and to perceive better investment behavior of this group, particularly in defective markets by assuming information asymmetry and agency problems.

\section{Theoretical bases and research literature}

Investment issue and related effect in achieving objectives of sustainable development is one of the very important and comprehensible subjects in Iranian economy (Roodposhti et al., 2011). What it stimulates investment in economy, is demand. The high demand will be led to higher cash flow with more capacity to meet the created demand and finally more predicted capital expenses. The free cash flow is a criterion to show cash funds at disposal of the enterprise after spending the needed expenses for maintenance or development of assets and they are deliverables among investments. According Theory of Free Cash Flow (FCF), as an enterprise creates excessive free cash flows while there are no available profitable investment opportunities, the director may tend to abuse free cash flows (Jensen, 1986), According to this theory, the enterprises with higher cash flow are more active in investment (Kato, 2002). Prediction of cash flows of an enterprise is deemed as an important basis in revealing corporate potential in investments and in making decisions for investment for the future periods (Frigo, 2003). There are some other factors rather than suitable opportunities to grow in investment including types of relations between directors and other beneficiaries who can affect corporate investors fundamentally (Tehrani \& Rahnama, 2014). If the minor investors estimate that the major investors use corporate financial sources for their own interests without regulatory and preventive mechanisms, the financing cost is increased in company and directors rely more on internal cash flows to provide the needed sources for investments and as a result the investment becomes more sensitive to variance of cash flow (Linz et al., 2005). Talebnia et al. expressed that rising of free cash flows which might be followed by tendency of directors to non-optimal spending of the given funds might increase agency problems (Talebnia et al., 2015). Given 
these documentations, it can be implied that mechanisms of corporate governance influence in investment.

\section{Research history}

In a study done by Tehrani and Hesarzadeh (2009), they examined effect of free cash flows and constraint of financing on overinvestment and underinvestment. Their findings showed that there was direct and significant relationship between free cash flows and overinvestment. Similarly, there is no significant relationship among constraint in financing and underinvestment in the company.

Mahmudabadi et al. (2013) explored quality of effect by free cash flows and agency costs on performance of the listed enterprises in Tehran Security and Exchange Organization (TSEO) and reported positive and significant relationship among free cash flows and evaluation criteria for corporate performance.

In another investigation, Afsordeh and Niazi (2015) examined effect of corporate governance on sensitivity of cash flows for investment in the listed enterprises in TSEO organization. Their results indicated that there was significant relationship among rate of institutional ownership, ownership focus, independence of directors and sensitivity of cash flows for investment. They believe that strong mechanisms of corporate governance in any enterprise may reduce financial constraints and sensitivity of cash flows for investment by optimal allocation of investment and these findings are based on agency theory.

Ibrahimi et al. (2016) explored competition in product market, free cash flow, overinvestment and underinvestment. They found that the positive and significant relationship to underinvestment and overinvestment based on Herfindahl- Hirschman Index (HHI). There is significant interactive relationship among free cash flow and Herfindahl- Hirschman Index (HHI) with underinvestment.

In a survey, Motaghi et al. (2017) examined the effect of mechanisms of corporate governance on reaction of investors in TSEO organization. Their findings showed that none of studied mechanisms of corporate governance (ownership of institutional shareholders, ownership focus, ownership structure and independence of directors) affected on reaction of investors in this investigation. 
Kevin et al. (2009) explored effect of agency costs caused by free cash flows on corporate investment cost. The results showed that the companies with major and influential investors had the lower agency cost due to free cash flow and thus lesser investment cost and they are stronger in controlling free cash flow. They introduced free cash flow as an index that could indicate potential risk caused by overinvestment of directors.

Francis et al. (2013) analyzed relationship between mechanisms of corporate governance and sensitivity of cash flows of investment. Their findings indicated that the mechanisms of corporate good governance reduced dependency of enterprises on cash flows inside the company and as a result financial constraints might be reduced for such enterprises.

Chen et al. (2013) examined effect of governmental and foreign ownership on investment return. Their findings indicated that governmental and foreign ownership might be related to information asymmetry and agency problems at different levels. Likewise, they argue that undermining of governmental ownership and strengthening of foreign ownership leads to rising of investment return. Likewise, they indicated that there was stronger relation among foreign ownership and investment return for the enterprises in which there was lesser governmental and institutional ownership.

Chen et al. (2016) examined free cash flow, overinvestment and corporate governance in China in their survey. They found that overinvestment was more sensitive to positive free cash flow in enterprises. In addition, some features of corporate governance are efficiently related to corporate investment.

\section{Methodology}

Whereas this study mainly aims to analyze effect of free cash flow and variables in corporate governance system on overinvestment at the listed enterprises in TSEO organization thus methodology includes determining relationship, correlation and regression and methodology of this study is of post hoc research (using previous information). Similarly, this study is theoretically of positivistic research group and it is of applied one according research classification based on objective and this study has been executed within framework of deductive- inductive reasoning. Namely, theoretical bases of research history have been collected by library and papers and deductive reasoning and in order to approve or reject hypotheses, inductive reasoning has been utilized and E-view software was used for data analysis. Likewise, the statistical population in this study includes the listed enterprises in 
TSEO organization during (2010-16) in which the fiscal year was ended to $21^{\text {st }}$ March. These enterprises did not change their fiscal year during the studied period and all information relation to elements of calculation for variables of equations are available and disclosed and they exclude from investment and financial brokerage companies, insurance companies and banks. Given the exerted constraints, 119 enterprises were selected. The given sample is selected by means of systematic deletion technique where the information of these enterprises has been collected from TSEO organization, TSEO website and Rahavard Novin software.

\section{Research hypotheses}

The relationship is examined between free cash flows and overinvestment and role of corporate governance in the enterprises listed in TSEO organization and the following hypotheses are interpreted with respect to subject of study:

$H_{1}$ : There is significant relationship among free cash flows and overinvestment in enterprise. $\mathrm{H}_{2}$ : The variables of corporate governance affect significantly relationship between free cash flows and overinvestment.

\section{Research model}

The following model is utilized to measure research hypotheses based on study done by Chen et al. (2017):

Model (1)

$$
I_{\text {uow }}=\alpha_{0}+\alpha_{l} F C F_{n}+\alpha_{2} \text { GOVERNANCE_FACTORS } S_{\text {it }}+\alpha_{3} \text { GOVERNANCE_FACTORS }
$$

$$
{ }^{*} F C F_{i t}+\varepsilon_{i t}
$$

\section{Operational definition of variables}

The overinvestment $\left(I_{\text {new }}\right)$ is the dependent variable in this study. Following to study of Chen et al. (2016), the equation below is obtained to measure overinvestment in this survey:

\section{Model (2)}

$$
I_{i t}=\boldsymbol{\alpha}_{0}+\boldsymbol{\alpha}_{1} V / P_{i t}+\boldsymbol{\alpha}_{2} L E V E R A G E_{i t}+\boldsymbol{\alpha}_{3} \mathrm{CASH}_{i t}+\boldsymbol{\alpha}_{4} 4 G E_{i t}+\boldsymbol{\alpha}_{5} S I Z E_{i t}+\boldsymbol{\alpha}_{0} \operatorname{Ret}_{i t}
$$

Where in the model above, $I_{i t}$ denotes investment, $V / P_{i t}$ as ratio of market value to book value, $L E V E R A G E_{i}$ as leverage, $\subseteq C A S H_{i t}$ sum of cash flows, $A G E_{i t}$ corporate age, SIZE $i t$ size of company, Retit stands for stock return rate of company i at year $t$ and $I_{, t-1}$ expresses investment rate in company $i$ at year $t-1$. 

market

Similarly, Free Cash Flow (FCF) is the independent variable in this study. The following equation is used for measurement of free cash flows:

$$
\text { Eq. (1) } \quad F C F_{i t}=C F_{\text {it }}-I_{\text {it }}
$$

In this equation, $C F$ denotes cash flows caused by operational transactions (Badavar Nahandi \& Taghizadeh, 2013) and $I$ as capital expenses.

Finally, GOVERNANCE_FACTORS $i$ is the moderator variable in this study. Variables of size of board of directors (Board Size), independence of directors (IndDir) and corporate institutional investor (Institutional) have been used for measurement of corporate governance in this investigation. Size of board represents magnitude of board of directors in the company and it is derived from logarithm of number of members of the board. Likewise, the percent of non-duty members of board in any company is utilized to determine independence of directors. Finally, Based on subject of Clause 27 of Article 1 of Act of IRI Securities Market for measurement of corporate institutional shareholders, the institutional shareholders include banks and insurance companies, holdings, investment companies, retirement fund, financing companies and investment funds registered before TSEO organization, any natural person or legal entity who buys more than $5 \%$ or more than 5 billion Rials of securities at face value under publication by publisher, governmental and public organizations and institutions, governmental agencies, members of directorate and publisher managers or individuals with the similar performance (Gord et al. 2015).

\section{Results}

Descriptive statistics: It is necessary to be familiarized with descriptive statistics concerning variables in order to determine general specifications of variables as well as for estimation of model their precise analysis. Descriptive statistics compute parameters of population and include central tendency and discrepancy of population parameters etc. Descriptive statistics of research variables including mean, median, maximum, minimum, and standard deviation are given in Table (1). 
Table 1

Descriptive statistics of research main variables

\begin{tabular}{|c|c|c|c|c|c|}
\hline Variable & Mean & Median & Maximum & Minimum & $\begin{array}{c}\text { Standard } \\
\text { deviation }\end{array}$ \\
\hline Overinvestment & -0.001638 & -270595.0 & 20755802 & -647695.5 & 1163230. \\
\hline Free cash flows & 630641.0 & 29047.00 & 38785921 & -20966756 & 3637753. \\
\hline Size of board & 0.743538 & 0.778151 & 0.954243 & 0.477121 & 0.052213 \\
\hline $\begin{array}{c}\text { Independence } \\
\text { of directors }\end{array}$ & 0.589900 & 0.600000 & 0.833333 & 0.142857 & 0.185352 \\
\hline $\begin{array}{c}\text { Institutional } \\
\text { shareholder }\end{array}$ & 54.88331 & 51.25000 & 89.58000 & 5.860000 & 18.50320 \\
\hline
\end{tabular}

Based on Table (1) among the studied enterprises, the mean values are for variables of overinvestment (-0.001638), free cash flows (630641), size of board (0.778151), independence of directors (0.5899), and institutional investor (54.88331). The maximum and minimum values are given for each of variables at the next column and finally the last column indicates standard deviation of variables showing data around mean value. This value is for variables of overinvestment (1163230), free cash flows (3637753), size of board (0.052213), independence of directors (0.185352), and institutional investor (18.50320).

Inferential statistics: E-view software has been utilized for analysis on research hypotheses in this study. For this purpose, the mixed data have been estimated for 119 enterprises. It should be identified this point before estimation of the model that it is not basically necessary to consider structure of panel data (corporate differences or specific effects) or one can merge the given data for various enterprises by pooling and use it for approximation of the model. Limer F-statistic test was used for making recent decision in single-equation approximations. The Hausman test was employed for determining fixed or random effect of difference in sectional units to specify which technique (fixed or random effects) might be appropriate for estimation; and Wooldridge test to detect autocorrelation; and Pagan-CokeWeisberg test for analysis of heteroskedasticity and finally Jarque-Bera test was utilized to measure normal distribution of elements. After ensuring from satisfaction of classic assumptions and in order to estimate the model, random effects techniques and aggregated least square technique and dependent variable model with 1 lag have been used for removal of autocorrelation. The following model has been utilized to analyze research hypotheses.

$$
\begin{aligned}
& I_{\text {new }}=\alpha_{0}+\alpha_{1} F C F_{\text {it }}+\alpha_{2} \text { GOVERNANCE_FACTORS } S_{\text {it }}+\alpha_{3} \text { GOVERNANCE_FACTORS } \\
& { }^{*} F C F_{\text {it }}+\varepsilon_{\text {it }}
\end{aligned}
$$

The given results from estimation of research model are described in Table (2). 

market

Table 2

Results of research hypotheses

\begin{tabular}{|c|c|c|c|c|}
\hline Variable & $\begin{array}{c}\text { Estimated } \\
\text { coefficients }\end{array}$ & Standard error & t-statistic & p-value \\
\hline Interceptor & 913652.0 & 108233.7 & 8.441474 & 0.0000 \\
\hline Free cash flows & 0.196900 & 0.052011 & 3.785741 & 0.0002 \\
\hline Size of board & -810930.2 & 125711.0 & -1.450752 & 0.0788 \\
\hline $\begin{array}{c}\text { Independence } \\
\text { directors }\end{array}$ & -277874.8 & 40206.40 & -0.911208 & 0.1975 \\
\hline $\begin{array}{c}\text { Corporate } \\
\text { institutional } \\
\text { investor }\end{array}$ & -1122.227 & 286.1957 & -3.921188 & 0.0001 \\
\hline $\begin{array}{c}\text { Free cash flows * } \\
\text { size of board }\end{array}$ & -0.470344 & 0.243048 & -1.935191 & 0.9661 \\
\hline $\begin{array}{c}\text { Free cash flows * } \\
\text { independence of } \\
\text { directors }\end{array}$ & 0.008042 & 0.189377 & 0.042464 & 0.0024 \\
\hline $\begin{array}{c}\text { Free cash flows * } \\
\text { corporate } \\
\text { institutional } \\
\text { investor }\end{array}$ & -0.001952 & 0.000639 & -3.054605 & \\
\hline AR (1) & 0.115758 & 0.028022 & F-Statistic significance: 0.00000 \\
\hline $\begin{array}{c}\text { AVE coefficient: } 0.556177 \\
\text { Durbin-Watson statistic: } 2.036123\end{array}$ & & & & 0.0000 \\
\hline
\end{tabular}

Table (2) shows the results of estimation of main model. According to the listed results in this table, P-value is lesser than $5 \%$ for F-statistic therefore it can be mentioned the model is significant for research hypotheses at confidence level (95\%) and it is highly valid with respect to higher value of determination coefficient $(0.55)$.

The results of first hypothesis: With respect to table of estimated coefficients of independent variable of free cash flows (3.785741) in Table (2), it indicates positive and significant relationship between free cash flows and overinvestment in the company at error level $(0.050$ because the calculated $\mathrm{p}$-value was derived less than 0.05 for coefficient of this independent variable at this study. Thus, it can be implied there is positive and significant relationship between free cash flows and overinvestment in the company so research hypothesis is approved.

Results of second hypothesis: The second hypothesis discussed about moderator role of corporate governance variables in relations between free cash flows and overinvestment. Given table of estimated coefficient for independent variable of size of board * free cash flows in Table (2) this value (-1.935191) indicates lack of significant relationship in free cash flows in relationship between cash flows and overinvestment through role of size of board in company at error level (0.05) since the calculated p-value has been derived greater than 0.05 for this independent variable in this study. Therefore, it can be mentioned that size of board does not 
significantly affect relationship between free cash flows and overinvestment so the research hypothesis is rejected. Likewise, review on estimated coefficient for independent variable of independence of directors* free cash flows in Table (2) this value (0.042464) shows the lack of significant relationship among free cash flows and relation between cash flow and overinvestment through role of independence of directors in the company at error level $(0.05)$ because the calculated $p$-value was obtained greater than 0.05 for coefficient of this independent variable of study. Therefore, it can be implied that variable of independence of directors has no significant effect on relationship between free cash flows and overinvestment so the research hypothesis is disproved. On the other hand, the estimated coefficient for independent variable of institutional investor* corporate free cash flows in Table (2) with value of (-3.054605) shows existing negative and significant relationship among variable of corporate institutional investor in relation between cash flows and overinvestment in the company at error level 0.05 because the rate of calculated p-value was obtained smaller than 0.05 for coefficient of this independent variable of study. Thus, it can be mentioned that variable of corporate institutional investor significantly affects relationship between free cash flows and overinvestment so the research hypothesis is verified. As a result, it converts positive relationship between free cash flows and overinvestment into negative and significant relationship.

\section{Discussion and conclusion}

With respect to limitation of sources and efficiency and in line with economic investment, the profitable units are always exposed to investment opportunities in order to make logical decisions. Inter alia, the personal interests are assumed as criterion among making decision and selection of projects by directors and in relation to investment opportunities. Thus, conflict of interests and information asymmetry may prevent from optimal investment. Hence, the profitable units should study and analyze rate of investment in the course of investment in various projects. With respect to importance of this subject, the current study reviewed relationship between free cash flows, overinvestment and corporate governance in the enterprises listed in TSEO organization.

The results of studied investigations showed that there was positive and significant relationship between free cash flows and overinvestment in the company. In other words, free cash flows may increase overinvestment in the company. It can be implied according to these findings that the free cash flows are deemed as a key factor in creating overinvestment and it is 
led to occurrence of some agency problems of information asymmetry issues. These results are consistent with findings from Yang and Jiang (2008), Biddel et al. (2009) and Chen et al. (2016).

Likewise, further studied investigations indicated that there was no significant effect between variables of corporate governance, size of board and independence of directors on relations among free cash flows and overinvestment and only variable of corporate institutional investor might affect this relationship. These findings confirm this point that the board of directors has no motive identically to supervise over corporate performance. In other words, members of the board do not play their regulatory role properly in the position of corporate governance while such a corporate governance mechanism may reduce power of directors to follow up their personal benefits and return lost trust to investors. These findings suggest lack of meritocracy in TSEO organization and this behavior prevents the enterprise from supervision costs. These findings contradict to studies done by Chen et al. (2016) and Biddel et al. (2009). Alternately, it can be implied the viewpoint of institutional investors may allow investors to remain as investor in enterprise adequately to be benefitted from supervision interests. These findings are compliant with study of Chen et al. (2016). No study has been conducted in Iran to examine effect of corporate governance on relationship between free cash flows and overinvestment therefore it is impossible for us to compare results of the current research with domestic studies. With respect to the results derived from this study concerning positive relationship between free cash flows and overinvestment in company, it is recommended to shareholders, owners and investors in Iranian capital market to pay attention to factor of free cash flows upon evaluation of investment and include this factor in their decision-making models since the free cash flows are assumed as a clear message about rising of overinvestment. Similarly, it is suggested to the researchers to examine role of internal and external factors in investment return in their study. And finally, it is suggested to them to explore effect of administrative structures on overinvestment in a survey.

\section{References}

Afsordeh, Mojtaba, Niazi, Rahim. (2015). Analysis of effect of corporate governance on sensitivity of investment cash flows in enterprises listed in Tehran Security and Exchange Organization TSEO. Monthly of management and accounting studies. Vol. 14, pp. 123-148.

Badavar Nahandi, Younes, Taghizadeh Khanghah, Vahid. (2013). Review on relationship among auditing quality and investment return, Journal of accounting and auditing studies of University of Tehran, vol. 72, pp. 19-42. 
Biddle, G. C., Hilary, G. and Verdi, R. S. (2009). How does financial reporting quality improve investment efficiency?. Journal of Accounting and Economics, 48, 112-131.

Chen, L., Chunlei, L., and Guanyu, W. (2013). Financial constraints, investment efficiency and corporate governance: Empirical evidence from China, Service Systems and Service Management (ICSSSM). 10th International conference.

Chen, X. Sun ,Y. Xu, X. (2016). "Free cash flow, over-investment and corporate governance in China. Pacific-Basin Finance Journal. Volume 37, pp. 81-103.

Francis, H., Hasan, I., Song. L. and Waisman. M. (2013). Corporate governance and investment cash flow sensitivity: Evidence from emerging markets. Emerging Markets Review, 15 (3), pp. $57-71$.

Frigo,M.L and Graziano, R. (2003). "Strategic decisions and cash flow ", Strategic Finance, vol. 85, pp. 8-31.

Gord Aziz, Mohammadi Mansur, Goldoust Majid. (2015). Review on relationship between corporate governance features and stored cash fund. Journal of accounting and auditing studies. Series 22, vol. 2, pp. 263-278.

Ibrahimi, Seyed Kazemi, Bahraminasab Ali, \& Parvaneh Sedigheh. (2016). Competition in product market, free cash flow, overinvestment and underinvestment.

Journal of empirical studies of financial accounting. $13^{\text {th }}$ year, viol. 50, pp. 129-148.

Jensen, M. C. (1986). Agency cost of free cash flow, corporate finance, and takeovers. Corporate Finance and Takeovers. American Economic Review, 76(2), pp. 124- 146.

Kato, K. H, Loewnstein, U. Tsay, W. (2002), "Dividend policy, cash flow, and investment in japan", Pacific-Basin Finance Journal 10, pp. 443- 473.

Kevin C.W. Chen, Zhihong Chen. (2009). "Agency Costs of Free Cash Flow and the Effect of Shareholder Rights on the Implied Cost of Equity Capital”.www. ssrn.com.

Lins, K.V., Strickland, D., and Zenner, M. (2005). Do non-U.S. firms issue equity on U.S. stock exchanges to relax capital constraints?, Journal of Financial and Quantitative Analysis, Vol. 40, pp. 109-133.

Mahmudabadi H., Mahdavi Gh., Fereidouni M. (2013). Review of effect of free cash flows and agency costs on performance of the listed enterprises in TSEO organization, Journal of accounting knowledge, series 4, vol. 12, pp. 111-130.

Moradi Javad, Bagheri, Hadi. (2014). The comparative analysis of effect of managerial narrowmindedness and equity to stock return management. Journal of accounting and auditing studies. Series 21, vol. 2, pp. 229-250. 

market

Motaghi Ali Asghar, Gharib Hojat, Ghavipanjeh Ramin. (2017). The effect of corporate governance mechanisms on reaction of investors in TSEO organization. Journal of accounting research. Vol. 24, Pp. 139-155.

Rahnamaye Roodposhti Fereidoun, Nikoomaram Hashem, Shahverdiani, Shadi (2011). Financial and strategic management, Tehran: Hakim Bashi Pub.

Talebnia, Ghodratollah, Desineh Mehdi, Moridi Fatemeh. (2015). The effect of management financing decisions on cash flows. Journal of financial accounting and auditing studies. Series 7, vol. 26, Pp. 87-106.

Tehrani Reza, Hesarzadeh Reza. (2009). Effect of free cash flows and constraint in financing on overinvestment and understatement. Journal of accounting studies. Vol. 3. Pp. 50-67.

Tehrani Reza, Rahnama Falavarjani, Rouhollah. (2014). Prediction of investment behavior of enterprises in TSEO organization using neural networks. Quarterly of assets management and financing. $2^{\text {nd }}$ year, vol. 3 , pp. 63-80.

Yang, J., and Jiang, Y. (2008). Accounting information quality, free cash flow and overinvestment: A Chinese study. The Business Review, 11(1), pp. 159-166. 